
\title{
Effect of Corporate Governance Factors and MSWG Activism on Cumulative Abnormal Returns Induced by Related Party Transaction
}

\author{
Jerry Koay Chew Chai ${ }^{*}$ and Kamarun Nisham Taufil Mohd ${ }^{2}$ \\ 'DISTED College, School of Business Administration, Malaysia; \\ cckoay@disted.edu.my \\ 2Universiti Utara Malaysia, School of Economics, Finance and Banking, Malaysia; \\ kamarun@uum.edu.my
}

\begin{abstract}
Objectives: This study examines the effects of RPT and corporate governance factors in the firms' daily Cumulative Abnormal Return of the stock price (CAR) in the emerging market of Bursa Malaysia. Methods/Analysis: This event study used a sample of 422 RPTs engaged by public listed firms in Malaysia. Univariate analysis (t-test) is used to determine the RPT's announcement effect on CAR in short horizon window, and the OLS regression to investigate the relationships between firm's CAR and the corresponding exogenous variables of Minority Shareholder Watchdog Group (MSWG) activism, RPT types and size, and the state of firm's corporate governance. Findings: Overall, this study pioneered a contribution, in Malaysian context, to the existing pool of literature on expropriation of minority shareholders via RPT. It directly measures the firm's CAR around the firm's RPT announcement period. Prior to this research, results with regards to expropriation of minority investors in the presence of RPT remain mixed and unclear in the Malaysian security market. It is also the first study to test and examine the impact of MSWG activism on the firm's CAR in response to the announcement effect of various types of RPT. The results shows significant negative CAR in the post-announcement of RPT, indicating governance discount of stock prices by the market in realizing occurrence of expropriation. The regression result shows controlling shareholder's ownership and the divergence of control to cash right have a significant positive association with expropriation of minority investors. It also provides evidence on the mitigating effect of MSWG activism on the controlling shareholders' expropriating behavior. Finally, past findings on the significance of board independence is reinforced by the result of this study. Novelty/ Improvements: This event study provides a comprehensive treatment of RPT associations with expropriation by controlling shareholders, firm's characteristics and the effectiveness of corporate governance practices in Malaysian listed firms.
\end{abstract}

Keywords: CAR, MSWG, Related Party Transaction

\section{Introduction}

Quality of minority interest protection is a key to growth and development of a country's security market. From a macroeconomic perspective, poor corporate governance and legal enforcement will result in liquidity and turnover problems, which deprive firms from financing valuable growth opportunities $\frac{1,2}{2}$. For a capital market to be globally competitive and at par with international jurisdiction, it needs to be recognized as a premier and stable market, which is well-regulated from an investor protection perspective $e^{1,3,4}$. This is in line with the Berle and

${ }^{*}$ Author for correspondence 
Mean advocates of voting rights, better disclosure policy and firm's managers' accountability ${ }^{-}$. Consequently, it is imperative to shift the focus of financial theory to the incentive and opportunity of controlling shareholders of the firm, in relation to the benefit and the expropriation of minority shareholders ${ }^{6}$.

The function of minority shareholder rights protection is governed by both firm-level and country-level variables in capital market. ${ }^{7}$ However, differences in the maturity, size, socio-political setting and efficiency of the stock markets in the world have resulted in variation of protection they provide in financial contracting $\frac{3,4,8}{3}$. The broad influence of minority interest protection issues has also led to scattered studies and findings in many different contexts of corporate finance, albeit a frequent linkage to the subject of the valuation effect on firm and financial performance.

Introduction of new provisions in 1986 and 1987 of the Company Act 1965 to restrain conducts of controlling insiders became a first major revamp in the history of Malaysian legislation on corporate governance. Following the Asian financial crisis in 1998, the Malaysian stock market suffered overwhelming loss of investors' confidence, as a result of corporate abuses such as RPT and asset transfer with conflict of interests between the controlling and minority shareholders ${ }^{9,10}$. Recognizing the significance of Corporate Governance (CG) in global capital market, Malaysian government actively pursued the transformation of Bursa Malaysia (Formerly called Kuala Lumpur Stock Exchange) to become a competitive player in emerging economies. Consequently, the Security Commission embarked on a major reform by implementing the code of corporate governance in March 2000. One of the key prescriptions of the code is the establishment of an audit committee with majority independent members, whereby one of its major functions is the oversight of RPT activities. To further improve investor protection, the Malaysian Code of Corporate Governance (MCCG) 2007 was enacted and subsequently enhanced in stages from 2008 to 2011. The key areas of code's revision for improvement are board independence, director's roles and responsibilities and rules of RPT disclosure. Bursa
Malaysia mandates a listed firm to disclose the detail of RPT promptly after agreement on the terms and conditions is sealed. It was found that disclosure requirements matter as firms tunnel using RPTs with disclosure exemptions ${ }^{\underline{11}}$.

However, despite stringent amendments of RPT rules via Companies Act 1965 since 2007, exploitation of weaknesses in the rules by controlling shareholders to expropriate minority investors remains a key issue in Bursa Malaysia. Evidences from recent years attesting to this concern are examples of abusive RPTs in Genting Malaysia, Tai Kwong Yokohama Berhad, Ho Hup Construction Company Bhd, Tradewinds (M) Bhd and Ceramtec Sdn Bhd. Furthermore, Malaysia dropped two places in ranking among 11 key Asian countries in a more recent corporate governance survey ${ }^{12}$.

On 30th August 2000, the Minority Shareholder Watchdog Group (MSWG) in Malaysia was founded and financially supported as a public company. The ultimate objective of MSWG is to raise shareholder value over time by building knowledge and understanding among Malaysian minority shareholders of their rights to pursue information, voicing their opinion and ask for the remedy. Its core activities of corporate monitoring has over the years progressed to become an independent research and reporting body on matters related to corporate governance and an advisor to minority shareholders on voting at general meetings of listed firms and as the platform for collective voices of retail and institutional minority investors.

Today's markets have become largely institutionalized where previous studies show the presence of equity block holders such as pension funds, mutual funds, hedge funds, and financial institutions actually provide monitoring benefits $\frac{19,20,21}{}$. Others found their credible threat of divestment will result in lower share price, hence alleviate managerial incentive problems $22,23,24,25$. Therefore, in spite of lacking direct influence on corporate decisions, it seems the mere presence of non-controlling large shareholders improve firm governance. For instance, a Malaysian study found the oversight of outside block holders, especially non-institutional block holding negatively associated 
with corporate diversification, which could be a potential abusive RPT $\stackrel{26}{\text {. }}$

Besides the paucity of researches on RPT in Malaysia, results of prior Malaysian studies did not employ the method of direct measurement of the valuation effect of $\mathrm{RPT}^{9,13,14}$. In examining the Belgian business groups on stock price reaction to announcement of equity sales, Buysschaert et al..$^{15}$ found no diversion of resource by controlling shareholders, albeit the sample size was small. On the other hand, the Korean business groups (Chaebols) tunneling study found other valuation of firms in the group rose, while the affiliated firm declined when instructed by principal to rescue firms in the group with poor performance via merger exercise. ${ }^{16}$ However, the controlling shareholder benefited via tunneling from the overall deal of expropriation. Using direct measurement, RPT study in Hong Kong listed firms showed at post announcement, the cumulative abnormal stock return (CAR) was negative in the presence of tunneling, where controlling shareholders seek private benefits at the expense of minority shareholders ${ }^{17}$. Hence, extant research results of the direct measurement approach using CAR show mixed evidences of expropriation. It remains unclear with regards to the effects of RPT on minority shareholders in the Malaysian security market.

This study will employ approach of measuring the firm's Cumulative Abnormal Return of the stock price (CAR) around RPT announcement period as a direct indication of expropriation. It is motivated by the aim to provide a better understanding of the protection of minority shareholders' interest in Bursa Malaysia. Hence, an investigation will be made on the announcement effect of RPT on the firm's CAR and its relationships with MSWG activism, and the firm's corporate governance factors of ownership structure and board composition. The research data can verify the impact of RPT in the Malaysian market and provides an understanding of the mechanism through which potential expropriation by the controlling shareholders might take place. An attempt will be made to answer the following questions: 1 . Do different types and sizes of RPT have different effects on CAR? 2. Do MSWG activisms affect CAR? 3. Do board composition and ownership structure affect CAR? 4.) Does the presence of government control block investors protect the minority shareholder's interest?

Overall, univariate analysis shows significant negative CAR in the post-announcement of RPT, indicating governance discount of stock prices by the market in realizing potential occurrence of expropriation. The same significant trend of negative CAR is also found in the overall category of transaction that is known to cause expropriation, in particular asset acquisition and cash payments RPT subsamples. Similarly, MSWG activism was found to have a significant effect on CAR at both before and after the announcement of RPT. The problem of expropriation is mainly attributed to circumstances of high dominant family ownership and low board independence, which is further exacerbated by entrenchment of the controlling shareholders. Nevertheless, the results also show that MSWG activism mitigates expropriating behavior of the controlling shareholders.

The organization of the other four sections in this study is as follows. Section two describes this research design and hypotheses development. Section three presents the sample description and analysis of the results. Finally, section four provides the conclusion.

\section{Materials and Methods}

\subsection{Research Design and Data Collection}

This is an event-study that employs quantitative methods of independent sample t-test and ordinary least squares regression. It explores the relationships between Cumulative Abnormal Returns (CAR) of firm's stock price and corporate governance variables in the presence of related party transaction. It uses mainly data from secondary sources: company's annual report published on the Bursa Malaysia website (detail on related party transaction, shareholding and ownership structure), Datastream (firms' stock prices), and MSWG database (companies under the activism program).

The population of the study is the public listed companies in Bursa Malaysia covering only firms on the Main 
Table 1. Categorization of Related Party Transactions

\begin{tabular}{|c|c|c|}
\hline No & Types of Transaction & Descriptions of Transaction Activities \\
\hline \multicolumn{3}{|c|}{ Category 1: Transactions that are known to cause expropriation of the minority investors in the firm } \\
\hline 1 & Asset acquisitions & $\begin{array}{l}\text { Transactions that involve the acquisition of tangible or intangible assets by } \\
\text { the listed company from a connected person or from a private company } \\
\text { majority-controlled by this person. }\end{array}$ \\
\hline 2 & Asset sales & $\begin{array}{c}\text { Transactions that involve the sale of tangible or intangible assets of the } \\
\text { listed company to a connected person or to a private company majority- } \\
\text { controlled by this person. }\end{array}$ \\
\hline 3 & Equity sales & $\begin{array}{l}\text { Transactions that involve the sale of equity stake in the listed company to a } \\
\text { connected person or a private company majority-controlled by this person. }\end{array}$ \\
\hline 4 & Trading relationships & $\begin{array}{l}\text { Transactions that involve the trade of goods and services between the listed } \\
\text { company and a private company (a non-subsidiary) majority-controlled by } \\
\text { a connected person. They can be a purchase or sales or both by the listed } \\
\text { company. }\end{array}$ \\
\hline 5 & Cash payments & $\begin{array}{c}\text { Transactions that involve direct cash payments by the listed company to } \\
\text { a connected person or to a company controlled by this person or to a } \\
\text { subsidiary (including loans and cash assistance) and the provision of cash } \\
\text { guarantees by the listed company for debts owed by the connected person } \\
\text { or by the companies controlled by this person }\end{array}$ \\
\hline 6 & Loan guarantees & $\begin{array}{l}\text { Provision of guarantee and indemnity by the listed company to a connected } \\
\text { person or to a company controlled by this person or to a subsidiary, for } \\
\text { debts owed by the connected person or by the companies controlled by this } \\
\text { person }\end{array}$ \\
\hline \multicolumn{3}{|c|}{ Category 2: Those possibly beneficial to the minority investors of the firm } \\
\hline 7 & Cash receipts & $\begin{array}{l}\text { Transactions that involve direct cash assistance or loans provided by the } \\
\text { connected person to the listed company }\end{array}$ \\
\hline 8 & Subsidiary relationship & $\begin{array}{l}\text { Transactions between a listed company and one of its subsidiaries. They } \\
\text { could involve acquisitions or sales of equity stakes or assets and trading } \\
\text { relationships }\end{array}$ \\
\hline \multicolumn{3}{|c|}{ Category 3: Those possibly having strategic motivations and is not an expropriation. } \\
\hline 9 & $\begin{array}{l}\text { Takeover offers and joint } \\
\text { ventures }\end{array}$ & $\begin{array}{l}\text { Cases in which the listed company receives a takeover offer by another } \\
\text { publicly listed company that holds a toehold, and cases in which the listed } \\
\text { company forms a joint venture or strategic alliance with another company } \\
\text { that already holds a stake in the listed company. }\end{array}$ \\
\hline
\end{tabular}

Source: 17. Cheung et al., 2006 
Market. Overall, 286 listed firms from a wide coverage of sectors are included. The study identifies and hand-collected samples starting from year 2008 to 2013 on related party transaction, via reviewing annual reports and individual verification of pertinent information disclosed by the firm for each of the 422 RPT samples used in the analysis.

RPT are classified into three broad categories according to their possible valuation effect on stock price (refer Table 1). They are Category 1 transactions which are known to cause expropriation, Category 2 transactions that are considered as possibly beneficial to the minority shareholders of the firm, and Category 3 transactions regarded as having strategic motivations and not an expropriation as well.

\subsection{Univariate Analysis}

In this study, the market model is used to predict the firm's stock return based on the assumption of a linear relationship between the stock return and return on the market portfolio as follows:

$R_{i t}=\alpha_{i}+\beta_{i} R_{m t}+\varepsilon_{i t}$

$\mathrm{R}_{\mathrm{it}}=$ Actual return observed for firm $\mathrm{i}$ at day $\mathrm{t}$.

$\alpha_{i}$ and $\beta_{i}=$ Market model parameters estimated using 170 days of the trading ( $t=-200$ to -31$)$ preceding the event window period of 60 days $(t=-30$ to +30$)$, whereby $\mathrm{t}=0$ is the day of RPT's announcement date.

$\mathrm{R}_{\mathrm{mt}}=$ The return of market at day $\mathrm{t}$ based on FTSEBursa Malaysia Emas Index (FBMEMAS).

$$
\varepsilon_{i t}=\text { Error term for firm } i \text {. }
$$

Therefore, the daily abnormal return $\left(\boldsymbol{A} \boldsymbol{R}_{i t}\right)$ is calculated as the difference between actual returns observed $\left(\boldsymbol{R}_{i t}\right)$ and the market model expected returns $\left(\boldsymbol{\alpha}_{i}+\boldsymbol{\beta}_{i} \boldsymbol{R}_{m t}\right)$ as follows:

$$
\mathrm{AR}_{\mathrm{it}}=\mathrm{R}_{\mathrm{it}}-\left(\alpha_{\mathrm{i}}+\beta_{\mathrm{i}} \mathrm{R}_{\mathrm{mt}}\right)
$$

The average abnormal return $\left(A A R_{t}\right)$ can be calculated by taking the cross-sectional mean of daily abnormal return for the $\mathrm{N}$ number of firms at day $\mathrm{t}$ as follows:

$$
\operatorname{AAR}_{\mathrm{t}}=1 / \mathrm{N} \sum \mathrm{AR}_{\mathrm{it}}
$$

Hence, the cumulative average abnormal return between the short-horizon window period of $\mathrm{T} 1$ and T2 can be calculated using formula below (MacKinlay, 1997):

$$
\begin{aligned}
& \mathrm{T}_{2} \\
& C A A R_{T 1, T 2}=\Sigma A A R_{\tau} \\
& \tau=\mathrm{T}_{1}
\end{aligned}
$$

Finally, the statistical significance of $\boldsymbol{C A A \boldsymbol { R } _ { T 1 , T 2 }}$ can be determined by using independent sample t-test with the following null and alternative hypotheses:

$\mathrm{H}_{0}$ : $\mathrm{CAAR}_{\mathrm{T} 1 \mathrm{~T} 2}$ is equal to zero. $\mathrm{H}_{1}: \mathrm{CAAR}_{\mathrm{T} 1, \mathrm{~T} 2}$ is different from zero.

For the rest of the sections in this study, $\mathrm{CAAR}_{T 1, T 2}$ will be abbreviated as CAR for the cumulative abnormal return of stock price, whereas, 'T1,T2' will be denoted by $(\mathrm{T} 1, \mathrm{~T} 2)$ which means days $\mathrm{T} 1$ to $\mathrm{T} 2$ window period for the CAR.

\subsection{Multivariate Analysis}

To examine the relationship of corporate governance variables with CAR that arises from the announcement effect of RPT, ordinary least square regression of cumulative abnormal return of the stock price (CAR) for the window period of $(-5,1)$ on the independent variables is carried out using the model below. Prior to performing regression analysis, Pearson's correlation matrix and variance inflation factors for the 18 independent variables were generated to identify and assess the presence of multicollinearity. Thereafter, in OLS regression, heteroscedasticity-robust standard error procedure is applied to eliminate potential estimation biases before 
an optimization is carried out using the sequential search method.

$$
\operatorname{CAR}_{i}=\beta_{0}+\beta_{1} S R P T_{i}+\beta_{2} A S R P T_{d i}+\beta_{3} E S R P T_{d i}+\beta_{4}
$$
$T R R P T_{d i}+\beta_{5} C P R P T_{d i}+\beta_{6} L G R P T_{d i}+\beta_{7} C R R P T_{d i}+\beta_{8}$ $S R R P T_{i}+\beta_{9}$ TOUJVRPT $T_{d i}+\beta_{10} M S W G_{d i}+\beta_{11} B I N D_{i}+$ $\beta_{12} C E O D_{d i}+\beta_{13} C O D O_{i}+\beta_{14}$ DCRDO $_{i}+\beta_{15}$ COGLIC $_{i}$ $+\beta_{16} P N_{S S B H}+\beta_{17}$ FSIZE $_{i}+\beta_{18} L E V_{i}+\varepsilon_{i}$

Where, $\mathrm{i}=$ firm, $\beta_{\mathrm{i}}=$ estimates and $\varepsilon_{i}=$ error terms.

\subsection{Hypothesis Development}

In this study, hypotheses are proposed to examine the effects of corporate governance factors on the cumulative abnormal return of stock prices under the influence of related party transaction in Bursa Malaysia. They serve to answer the research questions discussed earlier in section 1 .

\subsubsection{Related Party Transaction Hypotheses}

The transactions are driven by two contrasting motivations, which can be explained by the efficient transaction hypothesis in the case of minimizing transaction cost, and the conflict of interest hypothesis for the cases of earning manipulations and tunneling purposes ${ }^{28 .}$. Hence, there are both positive and negative aspects of RPT in relation to its effect on firm's valuation ${ }^{29}$.

\section{Size of RPT (SRPT)}

A study in the US listed firms found the industry-adjusted CAR associates negatively to size of RPT 28 . The investigation of earning management in China showed firm valuation has a significant negative relationship with the size of asset sales RPT, where firm overstated transaction prices to prop-up sales revenue $e^{30}$.

\section{Types of Related Party Transaction}

In the context of this study, RPT can be classified based on their effect on the minority shareholders of the public companies. Table 1 provides a detailed summary of these three categories of RPT to be considered in this research.
Category 1: RPT Known to Cause Expropriation RPT involving trading relationship and loan or cash assistance to the firm's directors was found to associate negatively with the industry-adjusted CAR $\stackrel{28}{ }$. In the RPT study of China, result showed controlling shareholders tunnelled and expropriated minority shareholders via asset sales and acquisitions (ASRPT, ESRPT), trade of goods or services (TRRPT), direct cash payment (CPRPT), and the loan or loan guarantees (LRRPT) ${ }^{27}$.

Category 2: RPT Possibly Beneficial to Minority Shareholders

In a study of revenue propping in China's state-owned firms, operating performance was found to have positive associations with cash receipts (CRRPT) and subsidiaries relationship RPT (SRRPT) ${ }^{27}$. On the contrary, other studies show the propping up on firm revenue and profit by the state-owned firms has negative connotation, as suggested by the prop-up hypothesis of Friedman $\frac{31,32,33}{}$. Similar motives were found in Taiwanese market with a concentrated ownership feature where firms committed to issue new share use trading relationships RPT to prop up firm performance. As a majority or sole voting stock holder, the subsidiary relationship RPT between the listed firm and its subsidiary are generally construed as beneficial to minority investors.

\section{Category 3: RPT Having Strategic Motivations}

The value maximizing theory posited that target firms in merger and acquisition generally earn positive CAR as the market tends to value the more complex RPT (TO\&JVRPT) positively ${ }^{34-37}$. This is also attested by other studies in Hong Kong and China where significant positive CAR was found for window $(-2,2),(0,1)$ and $(0,10)$ around the announcement of RPT ${ }^{17,38}$.

\subsubsection{MSWG Activism Hypothesis (MSWG)}

Previous studies directly related to the impact of MSWG activism on announcement effect of RPT are unavailable, albeit Becht found firms engaged by fund activists has a positive average announcement effect on CAR of 5.3\% for $(-3,3)$ window period. .9 Nevertheless, MSWG targeted 
companies in Malaysia are found positively associated with stock returns and earning increase, whereas, the nontargeted or control companies were not $\frac{18}{}$. This suggests MSWG activism has the unique role of value increasing for the firm, besides providing investment's education to the general public, especially the retail investors.

\subsubsection{Board Composition Hypotheses}

In this study, the board composition factor is characterized by two variables which are Board Independence and CEO Duality, Their relevant hypotheses are discussed in the following section.

\section{Board Independence (BIND)}

Numerous RPT studies in the past examined the direct impact of board independence on CAR but none has finding with a statistically significant result $\frac{17,40,41}{\text {. Nonetheless, }}$ Gao and Kling $\underline{42}$ found the governance mechanisms of board independence negatively related to tunneling operations, in their examination of asset expropriation via related party transaction in the Chinese market. In its major reform following the Asian financial crisis in 1998, the Security Commission of Malaysian Exchange prescribed the establishment of an audit committee with majority independent members to oversee RPT activities.

\section{CEO Duality (CEOD)}

The tradition of having the same individual holding CEO and chairman position is called "duality", which connotes a conflict of interest when the CEO chairs the board. CEO duality has a significant positive association with nonvalue adding diversification, which is a potential avenue for abusive RPT $\stackrel{26}{ }$.

\subsubsection{Ownership Structure Hypotheses}

There are four variables under the factor of ownership structure that affects CAR. The following section discusses these variables and their corresponding hypotheses.
Cash Ownership of Dominant Owner \& Director (CODO)

In line with Jensen and Meckling argument of manager's tendency to expropriate decreases with increasing ownership claims, other studies also found dominant founding family ownership positively related to firm's valuation $\frac{53-55}{}$. However, firms experience value discount when ownership concentration is beyond the optimal level, a sign of dominant owner's entrenchment when accumulate too much strategic power ${ }^{46}$.

Study in Hong Kong market found ownership concentration and poor disclosure of information have a significant negative association with $\mathrm{CAR}^{17}$. Indonesian study showed share ownership of directors is negatively associated with CAR, suggesting the entrenchment effect of board members resulted in a higher tendency for firms to engage in abusive RPT $\stackrel{47}{ }$.

Divergence of Control to Cash Right for Dominant Owner and Directors (DCRDO)

Around the announcement of related party transactions, Xiao's examination of the relationship between marketadjusted CAR and agency costs in Chinese listed firms showed divergence between control and cash right for ultimate owners have a significant negative association with CAR for windows of $(-10,1),(-2,2)$ and $(0,5)$, with highly pronounced governance discount for loan guarantees and cash payment RPT $\stackrel{48}{\text {. }}$

\section{Cash Ownership of Government Linked Investors or State} Government (COGLIC) and Presence of Non-State Block Holders (PNSBH)

Extant theoretical literatures tend to generally predict big institutional shareholders as an efficient watchdog $\frac{43,49}{\text {. }}$. At the point this research is undertaken, no previous studies in Malaysian context can be found in the relationship between cash ownership of government linked investor or state government and the valuation effect of RPT's announcement. Nevertheless, in Malaysia, share ownership of government linked investment companies (GLICs) was found positively associated with the firm's performance measures of ROE and $\mathrm{ROA}^{50}$. 


\subsubsection{Firm Size (FSIZE) and Leverage (LEV)}

Besides the corporate governance factors as discussed above, this study will also take into consideration the firm's size and leverage as control variables.

\section{Results and Discussion}

\subsection{Descriptive Statistics}

As shown in Table 2, the total value of RPT incurred during the six year period was RM83.432 billion. 365 transactions (86.5\%) worth RM63.049 billion (75.6\%) are transactions that are expected to cause expropriation of minority shareholders, 28 transactions $(6.6 \%)$ worth RM9.093 billion (10.9\%) are transaction possibly beneficial to the minority investors, and 29 transactions (6.9\%) worth RM11.292 billion (13.5\%) are transactions that are possibly having strategic motive and are not expropriations. Furthermore, $68.9 \%(290 / 422)$ or $58.2 \%$ of the total value of RPT is related to acquisition nd sales of firm's asset and equity, which are non-operations activities related, whereas, operations activities related RPT such as trading relationship and certain subsidiary relationship constitute only $20 \%$ of total RPT.

On the firms' characteristics (refer Table 3), the overall mean and median Firm Size is RM2.985 billion and RM494.5 million, respectively, with a mean and median leverage of 1.212 and 0.84 respectively. Firms receiving cash assistance RPT have the highest mean leverage of 2.230, which is almost twice the overall sample average, and also having substantially smaller average firm size of RM1.806 billion compared to overall sample mean of RM2.985 billion. Finally, RPT related to takeover offers and joint ventures has significantly lower mean and median leverages of 0.885 and 0.652 respectively.

On the corporate governance factors, the overall board composition is on average characterized by Board Independence of $45.2 \%$ and CEO Duality of $15.6 \%$. On the other hand, the ownership structure has mean characteristics of $41.66 \%$ Cash Ownership of Dominant Owner (91.9\% or 388/422 samples has a controlling shareholder with more than $20 \%$ control right), and a ratio of 1.237 for Divergence of Control to Cash Right for Dominant Owner. Overall, despite the high average Presence of Non-State Block Holder at 53.7\%, Cash Ownership of Government Linked Investor or State Government is relatively low at $3.62 \%$. The overall mean frequency of firms covered by MSWG Activism is $40 \%$, in which more sensitive RPT such as asset sales and cash receipts, which are non-operating activities, induced a higher level of activism at $50.6 \%$ and $60 \%$ respectively.

\subsection{Univariate Results}

In Table 4, the univariate analysis of the overall sample, CARs are positively significant for pre-announcement windows of $(-30,1),(-10,1)$ and $(-5,1)$, with values of $3.80 \%$ (p-value of 0.011 ), $1.95 \%$ ( $\mathrm{p}$-value of 0.019 ) and $1.49 \%$ ( $\mathrm{p}$-value of 0.022 ) respectively. However, in a post-announcement period of $(0,30)$, CAR turns significantly negative at $-1.50 \%$ (p-value 0.069 ). This shows that in general, the market realized the occurrence of expropriation by controlling shareholders only after the formal announcement of RPT, which supports the study of expropriation in Hong Kong market, where they found investors could not predict the firm's expropriation prior to the announcement of the RPT ${ }^{17}$. Post announcement, investor discounting of stock price could be attributed to information asymmetries between the majority and minority shareholders during the pre-announcement period ${ }^{43}$. A possible explanation is insider trading took place prior to the RPT announcement. Realizing that after the RPT announcement, the less informed minority outsiders who earlier did not have the privileged access to the insiders, imposed a governance discount on the stock price ${ }^{51}$.

\subsubsection{Transactions That are Known to Cause Expropriation}

In the overall category of transactions that are known to cause expropriation, a CAR trend similar to the overall sample is found (column 9 of Table 4). At sub-sample level of this RPT category, only asset acquisition and cash payments show negative significant t-test results over the $(0,30)$ window, with firm CAR of $-2.59 \%$ ( $\mathrm{p}$-value 0.029 ), 


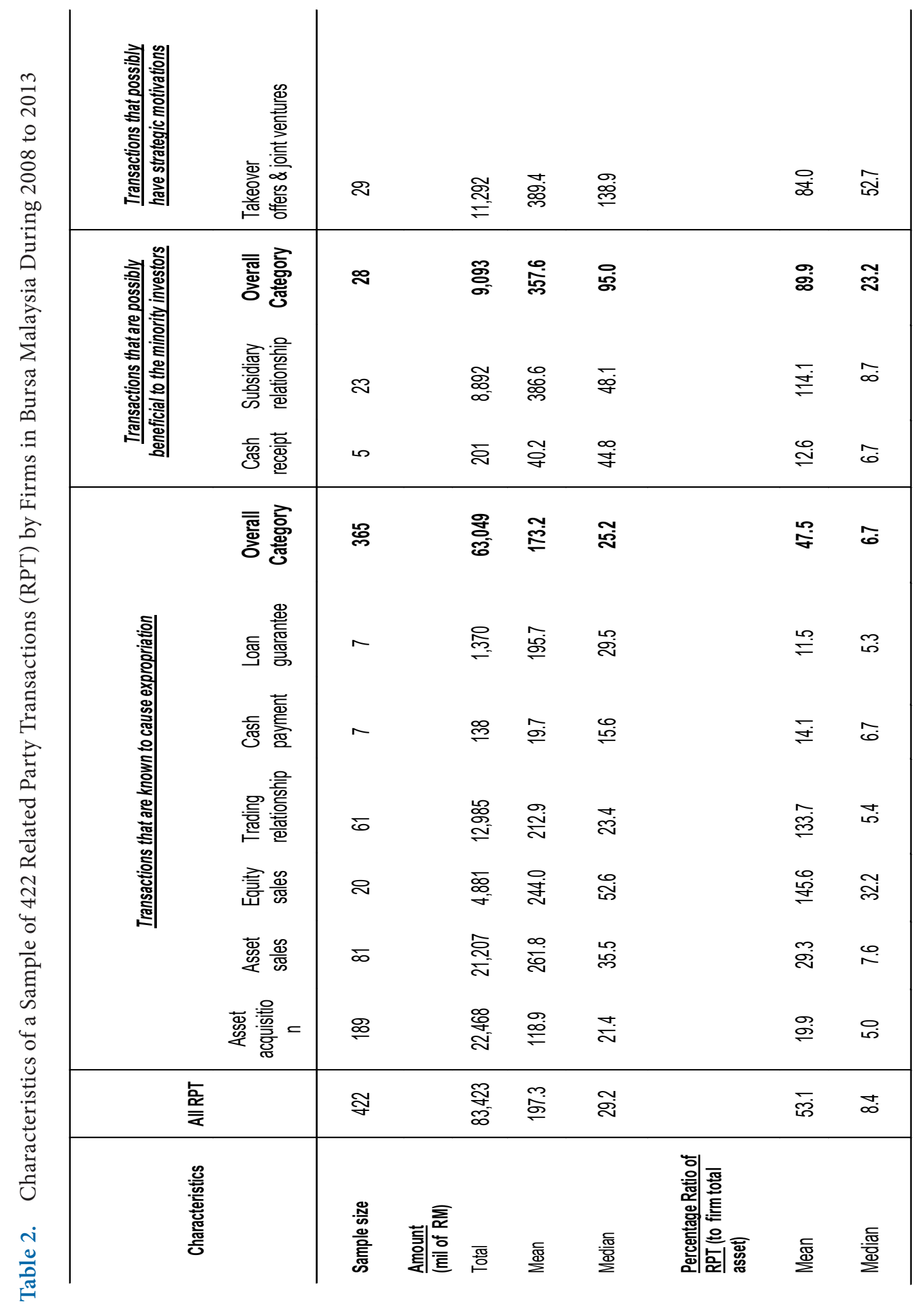


and $-11.13 \%$ (p-value 0.016 ) respectively, albeit with small subsample size for cash payment. Asset acquisition RPT shows negative significant relationship with CAR for a window period $(0,30)$. Hence, firms suffered value loss in response to the transaction's announcement. In line with the hypothesis, the asset acquisition of the listed firm from a related party is seen as a conflict of interest in the companies, and regarded by the shareholders as an act of expropriation. Subsequent to the RPT announcement, the firm's share price was discounted by investors. Cash payment RPT is hypothesized to have a negative impact on CAR, the results are highly significant for the post announcement period of $(0,1)$ and $(0,30)$ day windows, which are in line with our hypothesis. It also has a negative CAR throughout the entire short term event window period. Such a finding also supports the study by Gordon in US listed firms, where CAR had a significant negative relationship to the frequency and dollar value of lending to all the firm's directors ${ }^{28}$. In Table 3 , the cash payment transaction was found to be closely associated with smaller firms, albeit at a small sample size of 7 for this transaction category. These firms also have the lowest median leverage of 0.557 compared to the overall sample median of 0.840 (sample range 0.557 to 1.059). Hence, being relatively cash rich makes the firms more prone to engaging in this highly value-destroying transaction.

For the loan guarantee subsample, CAR for t-test results are not statistically significant except for the window $(0,1)$ with a $3.24 \%$ (p-value 0.088 ), which is different from the hypothesis. One possible explanation was the market perceived such related party transaction as something not immediately unfavorable to the firm in the short term, hence, not discounting the firm's stock price. However, the small sample size of seven RPTs warrants that the result should be interpreted cautiously.

Contrary to the hypothesis, the RPT of equity sales records positive significant effect on CAR during the period from the pre-announcement until the initial announcement, as indicated by the event window $(-30,1)$, $(-10,1)$ and $(-5,1)$. Firm undertakes equity sales over the pre-announcement day window earned an average of $11.07 \%$ (p-value 0.007), 6.36\% (p-value 0.002) and 4.27\% (p-value 0.040) abnormal return respectively, suggesting a probable positive impact of monitoring action by the connected persons. Furthermore, the willingness of the connected persons, who have private information about the company's performance, to buy equity in the company shows that they believe that the company is undervalued. Such market's reaction pattern showed a high resemblance to findings from studies in China and Turkey in which propping behavior of controlling shareholders were followed by serious engagement in tunneling activities. 27,31,32,52 However, from the result of this study, no evidence of tunneling can be established since the negative CAR in post announcement is not statistically significant.

The trading relationship RPT has a significant high positive CAR of $16.74 \%$ (p-value 0.060 ) in the pre-announcement period of $(-30,1)$ day window. It is noteworthy that the median leverage of the firms engaged in this RPT is 0.579 , which is considerably lower than the overall sample median of 0.84 . Such low gearing signal a high likelihood firms are free from financial distress. Besides, the frequency of the presence of nonstate block holders in these firms is the second highest at $70.5 \%$ (overall sample average is $53.7 \%$ ), and the average (median) combined share ownership of block holders is also the highest at $20.68 \%(19.31 \%)$ compared to the overall sample of $14.73 \%$ (11.63\%). This high presence of non-state block holders possibly gives signal to investors that managers of this type of RPT would not engage in opportunistic behavior as they are being monitored. Therefore, the factors of low leverage and high non-state block holders ownership very likely caused the market to perceive the RPT as routine or necessary business dealing, beneficial to the business operations of the listed firms. Hence, despite the presence of incomplete and asymmetric information phenomenon between the majority and minority shareholders during the pre-announcement period, firms still earn a favorable response of very high positive CAR from the market's investors.

Finally, the t-test result shows CAR of asset sales has a positive, statistically significant CAR for the day $(0,1)$ window, earning an abnormal return of $1.08 \%$ ( $p$-value 


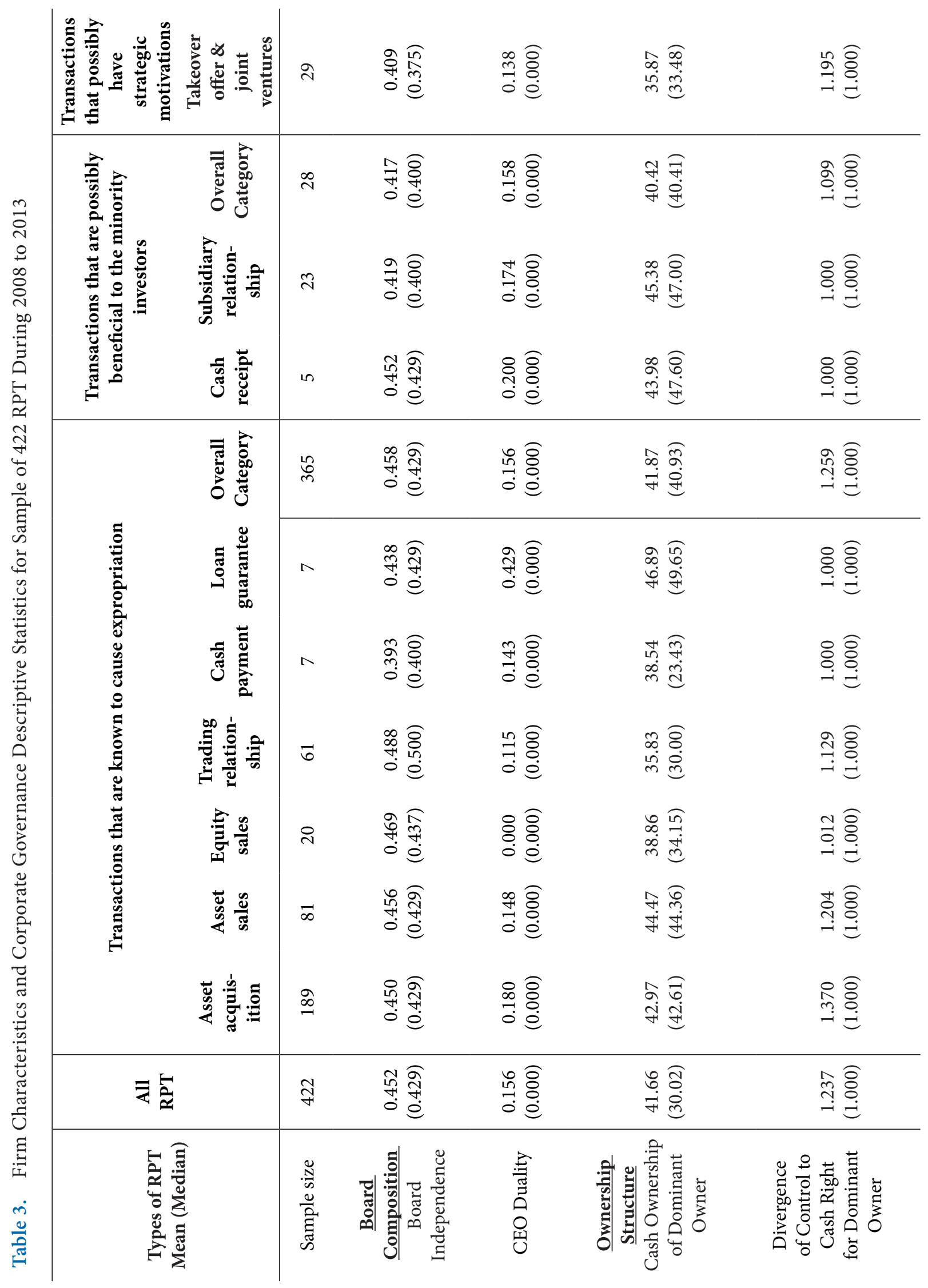




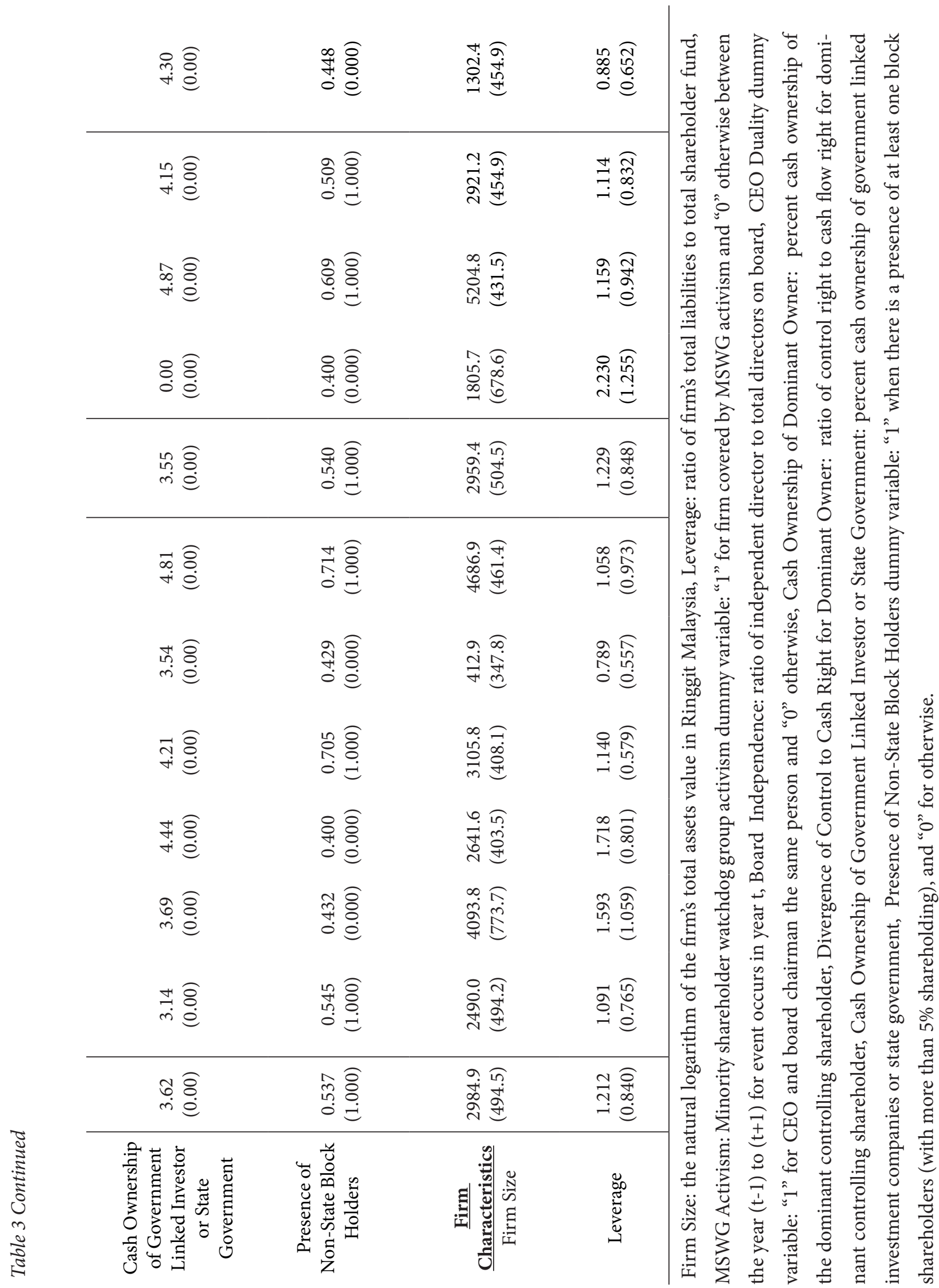




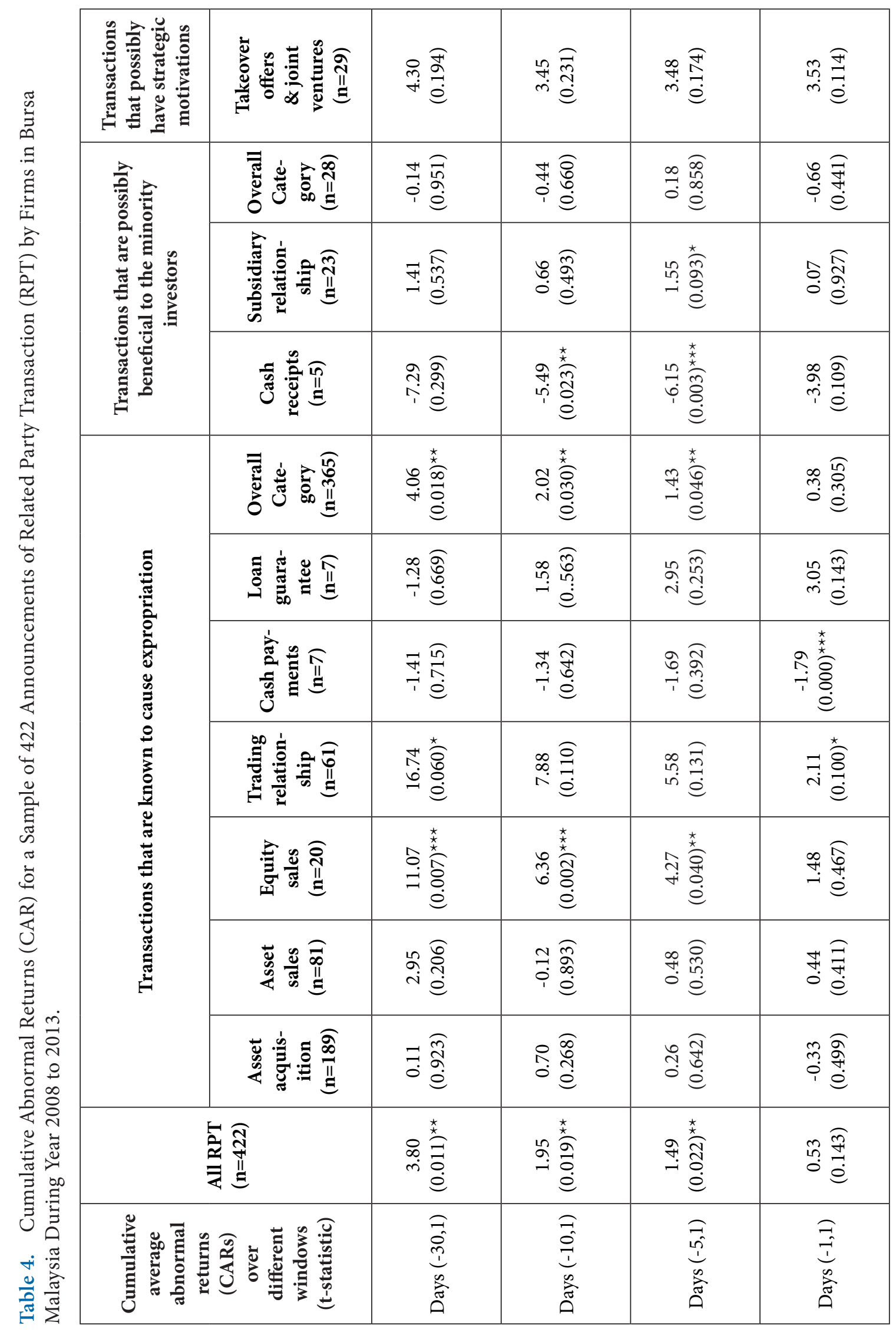




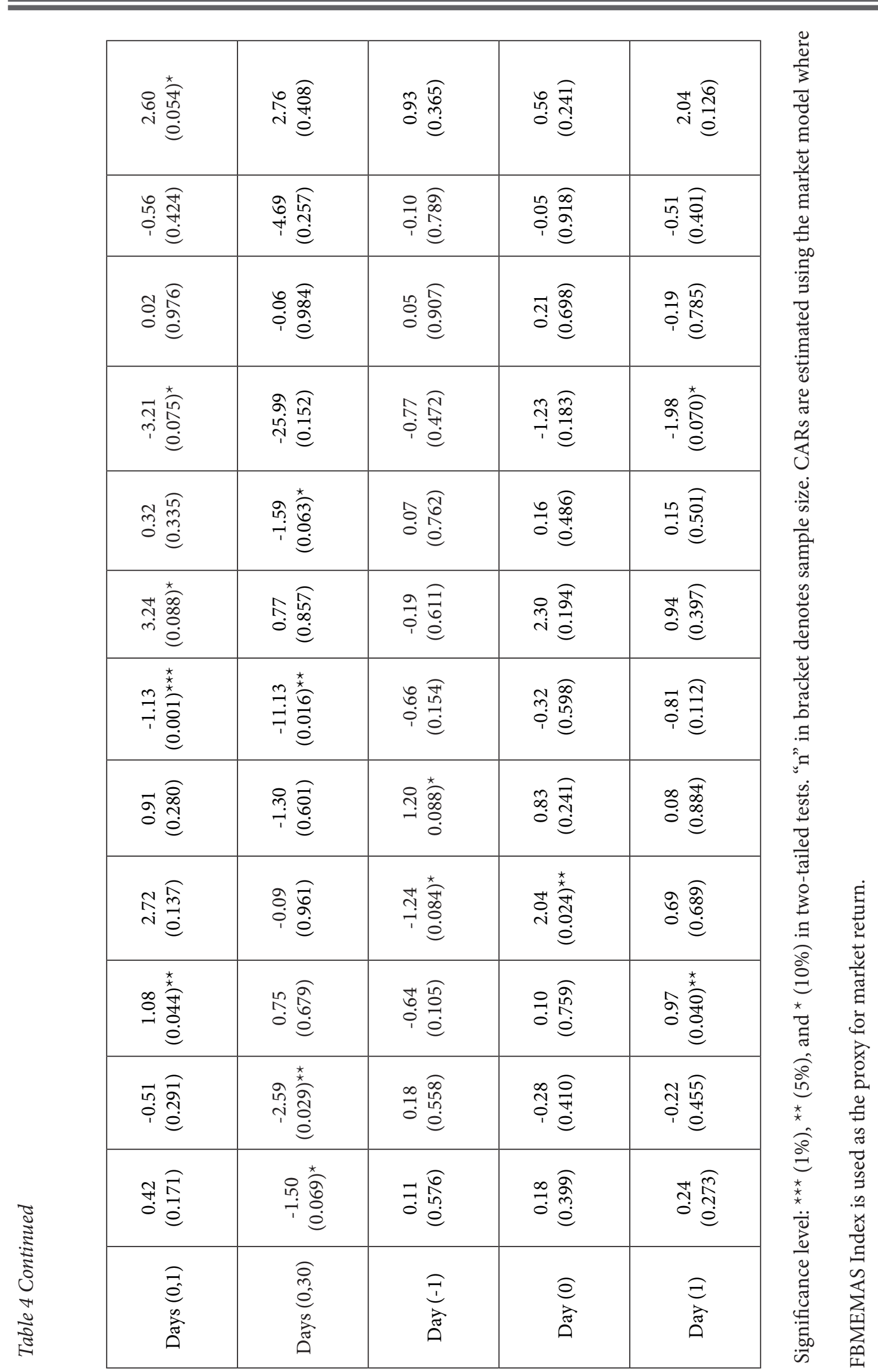


0.044). This finding is contrary to the expropriation hypothesis.

\subsubsection{Transactions that are Possibly Beneficial to the Minority Investors}

Friedman termed "propping up" such as cash receipts by the listed company from the dominant owner as the transactions that are likely beneficial to the minority shareholder. $\frac{33}{3}$ However, Table 4 shows result contrary to previous research findings, with a highly significant and strong negative CAR for cash receipt RPT. Over $(-10,1)$ and $(-5,1)$ day windows, the firms earned marketadjusted abnormal return of $-5.49 \%$ (p-value 0.023 ) and a $-6.15 \%$ (p-value 0.003 ) respectively. This suggests the market might distrust the actions and was highly suspicious of the motive of controlling shareholder who provided direct financial support to the listed firms. Hence, investors imposed a governance discount on the stock. An alternative explanation is the firms might have been already in a financial distress which explains the negative market reaction upon announcement. However, the small sample size of five RPTs requires that the result be interpreted cautiously.

On the other hand, the subsidiary relationship transactions show a positive significant relationship with CAR for the event window $(-5,1)$, earning a $1.55 \%$ (p-value 0.093 ) abnormal return, which supports our hypothesis of non-expropriation. The t-test result of the overall category transaction is not significant for all the six CAR window periods, when the two subsamples are tested as one combined overall category. This could be due to the effects of the larger dominant subsample of subsidiary relationship $(n=23)$ which are mainly non-significant except for window $(-5,1)$ having a significant positive CAR. However, this positive CAR impact is likely offset by the effect of the significant negative CAR which is also found in window $(-5,1)$ of the cash receipts subsample.

\subsubsection{Transactions that possibly have Strategic Motivations}

The t-test result of takeover offers and joint ventures RPT is statistically significant with a positive CAR of $2.6 \%$ (p-value 0.051$)$ for day $(0,1)$ window. This is in line with the hypothesis and findings from previous researches in Hong Kong and US 27,36 . They found the market generally does not appear to value negatively the more complex RPT such as those involving a firm's investment or partnership and joint venture.

\subsubsection{Monitoring by MSWG Activism}

In a further univariate analysis (Table 5), segregation of data into two different panel shows the monitoring effect of MSWG activism has a significant positive association with firm's CAR for windows $(-30,1),(-10,1)$, $(-5,1)$ and $(-1,1)$ and $(0,1)$ of pre-announcement period (Panel A of Table 5). These results show that firms being monitored by MSWG are more willing to engage in RPT activities when their share prices are on the rise as can be seen from the abnormal return of event window $(-30,1)$. Since these firms are being monitored by MSWG, they are signaling to the market that their RPT activities are not value decreasing. After the announcements of RPT activities, the abnormal return of these firms is a statistically insignificant value of $-1.20 \%$. Furthermore there is no evidence to suggest firms that engage in transactions that are known to cause expropriation suffer losses either before or after the announcements. In fact, these firms gain a statistically significant return of $7.89 \%$ before the announcements with no losses after the announcements. Furthermore firms that engage in transactions that are known to cause expropriation gain a statistically significant return of $7.89 \%$ before the announcements with no losses after the announcements. This is in contrast to the results of the group of firms that engage in transactions that are known to cause expropriation that is not being monitored by MSWG. For this group of firms, they do not earn abnormal returns before or surrounding the days of announcements, i.e., event windows of $(-30,1),(-10,1)$, $(-5,1)$ and $(-1,1)$ and $(0,1)$. However, after the announcements, they earned a significant abnormal return of $-2.52 \%$. These results show that for transactions that are known to cause expropriation, MSWG monitoring could lead to better returns. For the other two types of transac- 
tions, the results have to interpret carefully as the samples are very small.

\subsection{Multivariate Results}

OLS regression of CAR, using event window $(-5,1)$, on corporate governance variables (board composition, ownership structures and MSWG activism), RPT size and types, after controlling for firm characteristics (size and leverage), found the coefficients of 6 out of 18 independent variables are statistically significant (Model 3 of Table 6).

\subsubsection{Size and Type of Related Party Transaction}

Of the eight dummy variables (categorical dummy rep- resenting the 9 different types of RPT identified in this study, where Asset Acquisition RPT is defined as the "comparison or reference category" in regression analysis) in Table 6, only the negative coefficient of cash receipt sub-sample is statistically significant at the $1 \%$ level ( $p$-value 0.001). The result of significant negative coefficient for the Cash Receipt RPT Dummy variable is in line with the univariate analysis reported in Table 4 earlier, which also supports the hypothesis of this study.

\subsubsection{MSWG Activism}

The dummy variable of firms covered by MSWG Activism also has a positive coefficient that is statistically significant. It supports the hypothesis of this study in explaining

Table 5. Cumulative Abnormal Returns (CAR) for Sample of Announcements of Related Party Transaction (RPT) by Firms under MSWG Monitoring in Bursa Malaysia During Year 2008 to 2013

\begin{tabular}{|c|c|c|c|c|c|c|c|c|}
\hline \multirow[b]{2}{*}{$\begin{array}{c}\text { Cumulative } \\
\text { average } \\
\text { abnormal } \\
\text { returns } \\
\text { (CARs) } \\
\text { over } \\
\text { different } \\
\text { windows, } \\
\text { (t-statistic) }\end{array}$} & \multicolumn{4}{|c|}{ Panel A (Firms with Activism, MSWG = 1) } & \multicolumn{4}{|c|}{ Panel B (Firms without Activism, MSWG $=0$ ) } \\
\hline & $\begin{array}{l}\text { All RPT } \\
(n=168)\end{array}$ & $\begin{array}{c}\text { Transa- } \\
\text { ctions that } \\
\text { are known } \\
\text { to cause } \\
\text { exprop- } \\
\text { riation } \\
(\mathrm{n}=147)\end{array}$ & $\begin{array}{c}\text { Transa- } \\
\text { ctions that } \\
\text { are possibly } \\
\text { beneficial } \\
\text { to the } \\
\text { minority } \\
\text { investors } \\
(\mathrm{n}=9)\end{array}$ & $\begin{array}{l}\text { Transa- } \\
\text { ctions that } \\
\text { possibly } \\
\text { have } \\
\text { strategic } \\
\text { motivations } \\
(n=12)\end{array}$ & $\begin{array}{l}\text { All RPT } \\
(n=254)\end{array}$ & $\begin{array}{l}\text { Transa- } \\
\text { ctions that } \\
\text { are known } \\
\text { to cause } \\
\text { exprop- } \\
\text { riation } \\
(\mathrm{n}=218)\end{array}$ & $\begin{array}{c}\text { Transa- } \\
\text { ctions that } \\
\text { are possibly } \\
\text { beneficial } \\
\text { to the } \\
\text { minority } \\
\text { investors } \\
(\mathrm{n}=19)\end{array}$ & $\begin{array}{c}\text { Transa- } \\
\text { ctions that } \\
\text { possibly have } \\
\text { strategic } \\
\text { motivations } \\
(n=17)\end{array}$ \\
\hline Days $(-30,1)$ & $\begin{array}{c}6.79 \\
(0.044)^{* *}\end{array}$ & $\begin{array}{c}7.89 \\
(0.040)^{\star *}\end{array}$ & $\begin{array}{c}-3.2 \\
(0.461)\end{array}$ & $\begin{array}{c}0.77 \\
(0.716)\end{array}$ & $\begin{array}{c}1.82 \\
(0.104)\end{array}$ & $\begin{array}{c}1.48 \\
(0.223)\end{array}$ & $\begin{array}{c}1.31 \\
(0.626)\end{array}$ & $\begin{array}{c}6.79 \\
(0.212)\end{array}$ \\
\hline Days $(-10,1)$ & $\begin{array}{c}3.25 \\
(0.080)^{\star}\end{array}$ & $\begin{array}{c}3.78 \\
(0.073)^{\star}\end{array}$ & $\begin{array}{c}-2.44 \\
(0.228)\end{array}$ & $\begin{array}{c}1.02 \\
(0.626)\end{array}$ & $\begin{array}{c}1.10 \\
(0.083)^{\star}\end{array}$ & $\begin{array}{c}0.83 \\
(0.189)\end{array}$ & $\begin{array}{c}0.51 \\
(0.633)\end{array}$ & $\begin{array}{c}5.16 \\
(0.273)\end{array}$ \\
\hline Days $(-5,1)$ & $\begin{array}{c}2.55 \\
(0.065)^{*}\end{array}$ & $\begin{array}{c}2.97 \\
(0.059)^{*}\end{array}$ & $\begin{array}{c}-2.32 \\
(0.250)\end{array}$ & $\begin{array}{c}1.08 \\
(0.486)\end{array}$ & $\begin{array}{c}0.79 \\
(0.163)\end{array}$ & $\begin{array}{c}0.40 \\
(0.481)\end{array}$ & $\begin{array}{c}1.36 \\
(0.203)\end{array}$ & $\begin{array}{c}5.18 \\
(0.221)\end{array}$ \\
\hline Days $(-1,1)$ & $\begin{array}{c}1.02 \\
(0.061)^{*}\end{array}$ & $\begin{array}{c}1.28 \\
(0.033)^{\star *}\end{array}$ & $\begin{array}{c}-3.14 \\
(0.110)\end{array}$ & $\begin{array}{c}1.01 \\
(0.349)\end{array}$ & $\begin{array}{c}0.21 \\
(0.670)\end{array}$ & $\begin{array}{l}-0.22 \\
(0.646)\end{array}$ & $\begin{array}{c}0.52 \\
(0.367)\end{array}$ & $\begin{array}{c}5.31 \\
(0.153)\end{array}$ \\
\hline
\end{tabular}


Table 5 Continued

\begin{tabular}{|c|c|c|c|c|c|c|c|c|}
\hline Days $(0,1)$ & $\begin{array}{c}0.85 \\
(0.044)^{\star *}\end{array}$ & $\begin{array}{c}1.01 \\
(0.029)^{\star *}\end{array}$ & $\begin{array}{c}-2.69 \\
(0.129)\end{array}$ & $\begin{array}{c}1.64 \\
(0.069)^{\star}\end{array}$ & $\begin{array}{c}0.13 \\
(0.759)\end{array}$ & $\begin{array}{c}-0.15 \\
(0.750)\end{array}$ & $\begin{array}{c}0.46 \\
(0.338)\end{array}$ & $\begin{array}{c}3.27 \\
(0.142)\end{array}$ \\
\hline Days $(0,30)$ & $\begin{array}{c}-1.20 \\
(0.334)\end{array}$ & $\begin{array}{c}-0.23 \\
(0.854)\end{array}$ & $\begin{array}{c}-19.88 \\
(0.036)^{\star *}\end{array}$ & $\begin{array}{c}0.89 \\
(0.745)\end{array}$ & $\begin{array}{c}-1.70 \\
(0.122)\end{array}$ & $\begin{array}{c}-2.52 \\
(0.032)^{\star \star}\end{array}$ & $\begin{array}{c}2.51 \\
(0.426)\end{array}$ & $\begin{array}{c}4.08 \\
(0.450)\end{array}$ \\
\hline Day $(-1)$ & $\begin{array}{c}0.17 \\
(0.456)\end{array}$ & $\begin{array}{c}0.27 \\
(0.276)\end{array}$ & $\begin{array}{c}-0.44 \\
(0.487)\end{array}$ & $\begin{array}{c}-0.63 \\
(0.426)\end{array}$ & $\begin{array}{c}0.08 \\
(0.798)\end{array}$ & $\begin{array}{c}-0.07 \\
(0.820)\end{array}$ & $\begin{array}{c}0.06 \\
(0.896)\end{array}$ & $\begin{array}{c}2.03 \\
(0.214)\end{array}$ \\
\hline Day (0) & $\begin{array}{c}0.53 \\
(0.132)\end{array}$ & $\begin{array}{c}0.64 \\
(0.111)\end{array}$ & $\begin{array}{c}-0.81 \\
(0.149)\end{array}$ & $\begin{array}{c}0.27 \\
(0.615)\end{array}$ & $\begin{array}{c}-0.06 \\
(0.821)\end{array}$ & $\begin{array}{c}-0.15 \\
(0.591)\end{array}$ & $\begin{array}{c}0.31 \\
(0.630)\end{array}$ & $\begin{array}{c}0.77 \\
(0.295)\end{array}$ \\
\hline Day (1) & $\begin{array}{c}0.32 \\
(0.282)\end{array}$ & $\begin{array}{c}0.37 \\
(0.181)\end{array}$ & $\begin{array}{c}-1.89 \\
(0.223)\end{array}$ & $\begin{array}{c}1.37 \\
(0.027)^{\star *}\end{array}$ & $\begin{array}{c}0.19 \\
(0.567)\end{array}$ & $\begin{array}{c}0.00 \\
(0.977)\end{array}$ & $\begin{array}{c}0.15 \\
(0.756)\end{array}$ & $\begin{array}{c}2.51 \\
(0.266)\end{array}$ \\
\hline
\end{tabular}

Significance level: ${ }^{\star \star *}(1 \%),{ }^{* \star}(5 \%)$, and ${ }^{\star}(10 \%)$ in two-tailed tests.

the positive impact on market reaction to the announcement of a related party transaction in model 2. This variable is a proxy for the quality and disclosure of information via activism of shareholders under the leadership of the MSWG (Minority Shareholder Watchdog Group). Therefore, official disclosure of quality information is associated with positive abnormal return, and vice versa. The result indicates that firms under MSWG activism experience a positive market reaction when announcing related party transaction. In line with suggestion for emerging economies, high quality disclosures from companies make it more difficult for major shareholders to expropriate; hence safeguarding minority shareholders' interest. $\frac{53}{}$ It also complements the other findings where MSWG's activism was found not only having a positive association with the firm's performance, it also has a positive impact on the relationship between institutional ownership and corporate governance ${ }^{18,54}$.

\subsubsection{Board Composition}

Under the board composition factor, the coefficient of the Board Independence variable (model 2) is positive and statistically significant ( $\mathrm{p}$-value 0.068 ), as hypothesized in this study. This indicates the market reacted positively to a higher degree of board independence or a bigger number of independent directors' representation in the board. This suggests increased independence of board enhances its effectiveness as an advocate for the interests of shareholders via a board's mandatory monitoring role, such as the audit function, which must comprise of only independent directors. CEO Duality which was hypothesized to have a negative relationship with CAR is found insignificant in this study. While various studies concluded that CEO Duality is negatively associated with firm performance (TobinQ ratio), others suggested the presence of block holders (which is high in this study with an average frequency of 53.7\%) will negate the presence of CEO 
Table 6. Regression of Cumulative Abnormal Return (CAR) on Variable of Corporate Governance, Firm Characteristics and RPT for a Sample of 422 Related Party Transactions by Firms Listed in Bursa Malaysia During 2008 to 2013

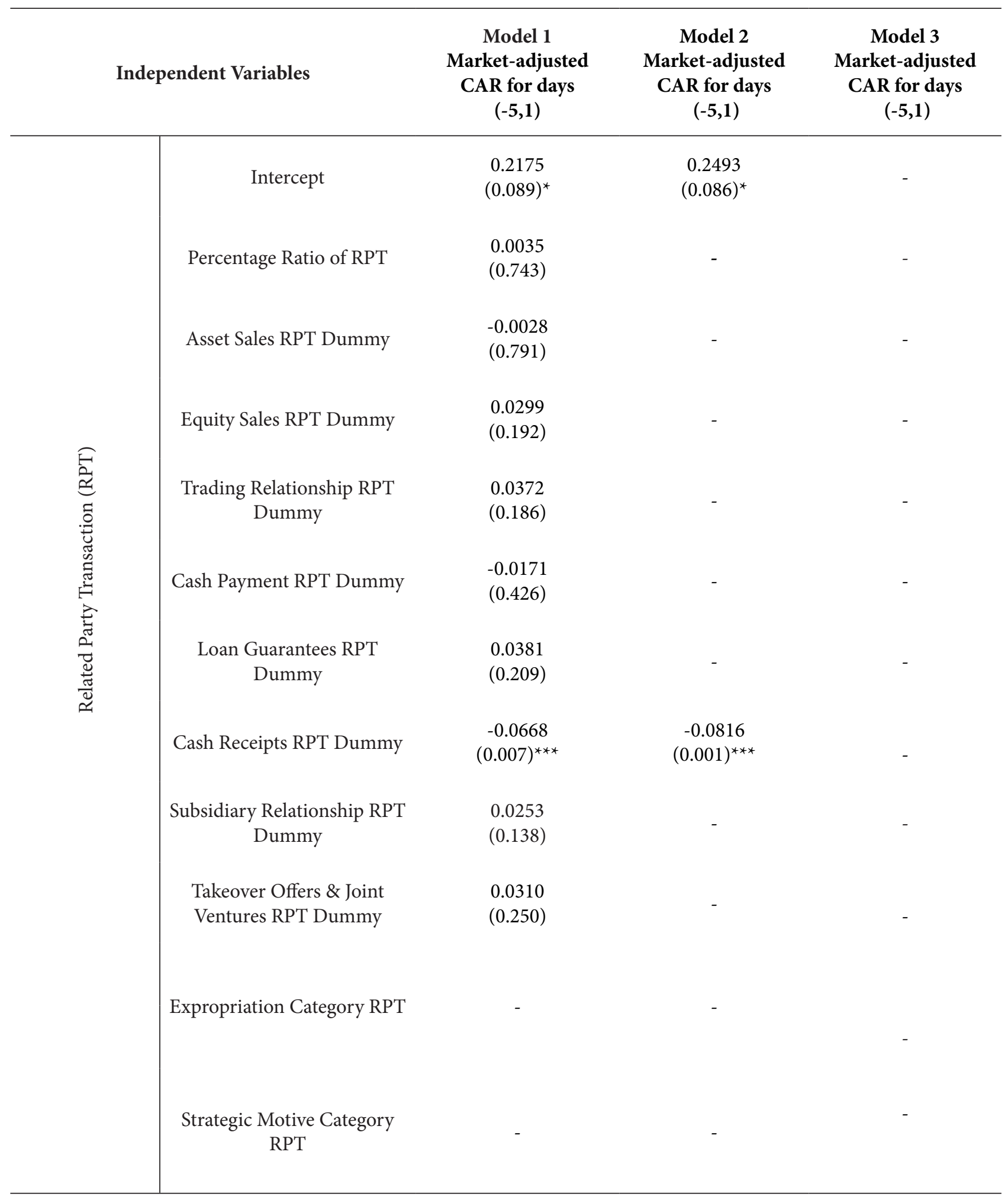


Table 6 Continued

\begin{tabular}{|c|c|c|c|c|}
\hline 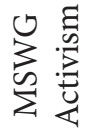 & MSWG Activism Dummy & $\begin{array}{l}0.0409 \\
(0.109)\end{array}$ & $\begin{array}{c}0.0427 \\
(0.010)^{\star *}\end{array}$ & - \\
\hline 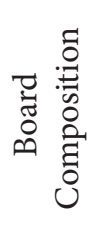 & $\begin{array}{l}\text { Board Independence } \\
\text { CEO Duality Dummy }\end{array}$ & $\begin{array}{l}-0.0034 \\
(0.791)\end{array}$ & $\begin{array}{c}0.1693 \\
(0.068)^{\star}\end{array}$ & $\begin{array}{c}0.1884 \\
(0.078)^{\star}\end{array}$ \\
\hline \multirow{3}{*}{ 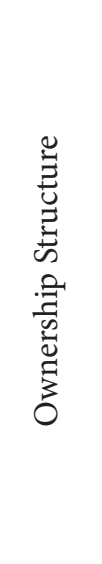 } & $\begin{array}{l}\text { Cash Ownership of } \\
\text { Dominant Owner }\end{array}$ & $\begin{array}{l}-0.0004 \\
(0.054)^{\star}\end{array}$ & $\begin{array}{l}-0.0006 \\
(0.014)^{\star *}\end{array}$ & $\begin{array}{l}-0.0007 \\
(0.011)^{\star *}\end{array}$ \\
\hline & $\begin{array}{c}\text { Divergence of Control to } \\
\text { Cash Right for Dominant } \\
\text { Owner } \\
\text { Cash Ownership of } \\
\text { Government Linked Investor } \\
\text { or State Government }\end{array}$ & $\begin{array}{l}-0.0021 \\
(0.157)\end{array}$ & $\begin{array}{l}-0.0032 \\
(0.075)^{\star}\end{array}$ & $\begin{array}{l}-0.0037 \\
(0.064)^{\star}\end{array}$ \\
\hline & $\begin{array}{c}\text { Presence of Non-State Block } \\
\text { Holder Dummy }\end{array}$ & $\begin{array}{l}-0.0017 \\
(0.864)\end{array}$ & - & - \\
\hline \multirow{6}{*}{ 福 } & Firm Size & $\begin{array}{l}-0.0137 \\
(0.082)^{\star}\end{array}$ & $\begin{array}{l}-0.0148 \\
(0.096)^{\star}\end{array}$ & - \\
\hline & Leverage & $\begin{array}{l}-0.0022 \\
(0.398)\end{array}$ & - & - \\
\hline & Sample size & 422 & 422 & 422 \\
\hline & Adjusted $\mathrm{R}^{2}$ & 0.056 & 0.066 & 0.040 \\
\hline & P-value (F) & 0.083 & 0.020 & 0.091 \\
\hline & VIFs & $1.048-3.019$ & $1.049-2.117$ & $1.216-1.923$ \\
\hline
\end{tabular}

Model 1:OLS regression using heteroskedasticity-robust standard errors.

Model 2:Optimized OLS regression by sequential search method (backward estimation) using heteroskedasticityrobust standard errors for days $(-5,1)$ window, based on the nine types of RPT. 
Table 6 Continued

Model 3:Optimized OLS regression by sequential search method (backward estimation) using heteroskedasticity- robust standard errors for days $(-5,1)$ window, based on three categories of RPT.

Percentage Ratio of RPT: ratio of RPT value to company's total assets, Asset Sales RPT: dummy variable '1' for yes, '0' for no, Equity Sales RPT : dummy variable '1' for yes, '0' for no, Trading Relationship RPT : dummy variable "1" for yes, '0' for no, Cash Payments RPT: dummy variable '1' for yes, '0' for no, Loan Guarantee RPT: dummy variable '1' for yes, '0' for no, Cash Receipts RPT: dummy variable '1' for yes, '0' for no, Subsidiary Relationship RPT: dummy variable ' 1 ' for yes, '0' for no, Takeover Offers \& Joint Ventures RPT: dummy variable '1' for yes, '0' for no, Expropriation Category RPT: dummy variable '1' for yes, '0' for no, Strategic Motive Category RPT: dummy variable '1' for yes, '0' for no. MSWG Activism: dummy variable: '1' for firm covered by MSWG activism and '0' otherwise, Board Independence: ratio of independent directors to total directors on board, CEO Duality: dummy variable: ' 1 ' for duality of CEO and '0' for non-duality of CEO, Cash Ownership of Dominant Owner: percent cash ownership of the controlling shareholder, Divergence of Control to Cash Right for Dominant Owner: ratio of control over cash flow right for dominant owner, Cash Ownership of Government Linked Investors or State Government: percent cash ownership government linked investor or state government, Presence of Non-State Block Holders: dummy variable ' 1 ' for presence of non-state block holder and '0' otherwise, Firm Size: logarithm of total assets of firm. Leverage: ratio of firm's total liabilities to total shareholder fund.

duality in the firm $\frac{19}{}$. Such impact could have possibly caused the insignificance of CEO Duality in the regression analysis.

\subsubsection{Ownership Structure}

For the ownership structure category, variables of Cash Ownership of Dominant Owner (CODO, p-value 0.014) and Divergence of Control Right of Dominant Owners ( $\mathrm{p}$-value 0.075), have negative coefficients that are statistically significant in model 2 . These results indicate increasing ownership of dominant owner is associated with firms experiencing more negative market reaction when announcing a related party transaction. Such negative market reaction is further exacerbated by the divergence of control to cash right for controlling shareholders. This is in accordance with the entrenchment effect theory of the disproportional structure of familyowned firms, where the presence of wedge in control and ownership rights was strongly correlated to firm's valuation discount ${ }^{17,55}$

However, the coefficients of the other variables in model 3, which are Cash Ownership of Government Linked Investor or State Government (COGLIC) and Presence of Non-State Block Holders (PNSBH)) are not statistically significant. The extant theoretical researches which tend to predict big institutional shareholders as efficient watchdog prompted the hypothesis of the above variables having a relationship with firm's CAR in this study. For instance, the sovereign wealth funds, which have the advantage of processing more superior information over their private counterparts. Hence their presence will generally give a stronger signalling effect to the firm's stock price. ${ }^{56}$ However, the average (median) ownership of COGLIC is very low at $3.62 \%(0.00 \%)$, with only two firms having GLICs as dominant owner with greater than $20 \%$ control right. Even though there are 127 sam- 
ples involving 90 firms that have GLICs ownership of at least 5\% and above, only 21 samples are without dominant family owners with at least $20 \%$ controlling right. Consequently, the effect of the influence of the CODO variable, which is significant in the regression, has possibly offset the impact of COGLIC variable, making it insignificant in the regression result.

It was hypothesized the Presence of Non-State Block Holders have a relationship with CAR. Ownership participation of large outside block holder can provide monitoring benefits to the minority shareholders. Studies in the Korean market found such evidences with CAR of $3.73 \%$ and $15 \%$ respectively after their corresponding events' announcement ${ }^{57,58}$. However, in the US study, the effect was otherwise, suggesting governance discount by market due to possible collusion between controlling shareholders and block holders to expropriate the firm ${ }^{59}$. Even though sample data shows $53.7 \%$ (refer to first column of Table 3) PNSBH, the effect on CAR is insignificant. Furthermore, block holders and institutional holder are also not keen to directly govern the firm due to lack of relevant skills and knowledge, and would react in the worst case by simply selling off their interest. This could again be explained by the offsetting effect of the above mixed previous empirical findings possibly relevant to this study, and the abstinent behavior of block holders when it comes to effective shareholder activism.

\subsubsection{Firm Characteristics}

While both Firm Size and Leverage variables of firms show a negative relationship with CAR, only Firm Size is found to have a statistically significant negative coefficient. This finding is consistent with the study whereby market imposed penalties on publicly traded firms with alleged misconducts, wealth loss is found to increase with bigger firm size. ${ }^{60}$ This is due to larger firms with more subsidiaries have a higher probability of engaging in RPTs that are prone to become a target for expropriation. Studies in Hong Kong and Korea also indicated that CAR has a significant negative association with firm size ${ }^{\frac{16,17}{}}$. However, a global study of acquisition deals in 47 coun- tries showed firm size positively related to CAR for $(-2,2)$ day event window 2 .

On the other hand, previous studies also found the firm leverage factor having a mixed relationship with CAR or firm's valuation, even though in this study, it is not particularly significant in explaining the market's response.

\subsubsection{Robustness Check}

As shown in model 3 of Table 6, an alternative estimation is employed by using the three categories of RPT namely, Expropriation Category RPT, Beneficial Category RPT and Strategic Motive Category RPT, instead of using individual RPT type as in model 2. Regression result also shows the coefficients of Board Independence ( $p$-value 0.078), Cash Ownership of Dominant Owner (p-value 0.011) and Divergence of Control Right of Dominant Owners (p-value 0.064) are statistically significant. Except for the MSWG Activism and Firm Size variables which become insignificant, model 3 shows a trend similar to model 2 in terms of negative signs and magnitude of the estimates for the significant variables.

\section{Conclusion}

Contrary to the widely held image of Berle and Means where firms have diverse share ownership, La Porta contended that worldwide corporate ownership of firms is typically controlled by families or state, with an ultimate owner. $\frac{5,6}{}$ In this study, firms undertaking a related party transaction have the mean and median cash ownership of $41.66 \%$ and $30.02 \%$, respectively, which are high in comparison to the $27.3 \%$ broader market average of family-controlled shareholdings in Bursa Malaysia ${ }^{14,61}$.

Even though it was argued that firms with foundershareholders having a family interest can provide better quality oversight, it appears that in Bursa Malaysia, dominant shareholder's ownership has a negative association with CAR in the related party transaction. Furthermore, the negative relationship is exacerbated by the divergence of the control to cash flow right. This combination of find- 
ings provides strong support for the presence of minority shareholders' expropriation.

On the other hand, the presence of MSWG activism has a positive announcement effect on CAR, which seems to suggest firms with higher disclosure quality via engagement of shareholder activism mitigates expropriation of minority shareholders. Similarly, the board independence factor which could be an indication of good governance was also found to have a positive impact on protecting the interest of minority shareholders. The high positive coefficient of Board Independence variable in regression denotes the importance of having a large percentage composition of independent directors, in order to negate the private benefit seeking behavior of the controlling shareholders.

However, in this study, there is no evidence found from the estimation results pointing to the participation of public investment fund or block holders having a significant positive attribute for deterrence of expropriation by the dominant owner via RPT.

\section{References}

1. Modigliani F, Perotti E. Protection of minority interest and the development of Security markets. Managerial and Decision Economics. 1997; 18:519-28. https://doi.org/10.1002/ (SICI ) 1099 - 1468(199711/12) 18:7/8<519::AID MDE857>3.0.CO;2-M.

2. Croci E, Petmezas D. Minority shareholders' wealth effects and stock market development: evidence from increase-inownership M\&As. Journal of Banking and Finance. 2010; 34:681-94. https://doi.org/10.1016/j.jbankfin.2009.09.003.

3. Hacimahmutoglu S. The problems of minority protection and their solutions within the legal framework in Turkish corporate governance. Journal of Banking Regulation. 2007; 8(2):131-58. https://doi.org/10.1057/palgrave.jbr.2350046.

4. Chandrasekhar K, Sevic A, Sevic Z. Legal environment, firmlevel corporate governance and expropriation of minority shareholder on Asia. Economic Change and Restructuring. 2005; 38:85-111. https://doi.org/10.1007/s10644-0054524-4.

5. Berl A, Means G. The Modern Corporation and Private Property. New York, McMillan: 1932.

6. La Porta R, Lopez-de-Silanes F, Shleifer A. Ownership around the world. The Journal of Finance. 1999 April; 14(2):471571. https://doi.org/10.1111/0022-1082.00115.
7. Doidge C, Karolyi G, Stulz, R. Why are foreign firms listed in the US worth more? Journal of Financial Economics. 2004; 71:205-38. https://doi.org/10.1016/S0304405X(03)00183-1.

8. Djankov S, La Porta R, Lopez- de-Silanes, F, Shleifer, A. The law and economics of self-dealing, Journal of Financial Economics. 2008; 88: 430-465. https://doi.org/10.1016/j. jfineco.2007.02.007.

9. Chan W. Expropriation Through Related Party Transactions: The Position In Malaysia. IABR and ITLC Conference Proceedings, Orlando, Florida, USA. 2010.

10. Bursa Malaysia Securities Berhad, High Level Finance Committee Report on Corporate Governance (1999): para 1, Chapter 1 \& para 1.6 Chapter 3. 1999.

11. Lei A, Song, F. Connected transactions and firm value: Evidence from China-affiliated companies. Pacific-basin Finance Journal, 2011; 19:470-90. https://doi.org/10.1016/j. pacfin.2011.07.002.

12. CLSA CG Watch 2007. Corporate governance in Asia, Regional Special Report, Credit Lyonnais Securities Asia. September 2007.

13. Liew C, Fazilah S, Sa'adiah, M. Expropriation-related variables \& firm performance: Evidence from Malaysian family firms, unpublished. 2012.

14. Munir S, Mohd Salleh N, Jaffar R, Yatim, P. Family ownership, related-party transactions and earning quality. Asian Academy of Management Journal of Accounting and Finance. 2013; 9(1):129-53.

15. Buysschaert A, Deloof M, Jegers M. Equity sales in Belgian corporate groups: expropriation of minority shareholders? A clinical study. Journal of Corporate Finance. 2004; 10:81103. https://doi.org/10.1016/S0929-1199(02)00047-0.

16. Bae K, Kang J, Kim J. Tunneling or value added? Evidence from mergers by Korean business groups. Journal of Finance. 2002; 57:2695-740. https://doi.org/10.1111/15406261.00510.

17. Cheung Y, Rau P, Stouraitis A. Tunelling, propping, and expropriation: evidence from connected party transactions in Hong Kong. Journal of Financial Economics. 2006; 82:343-86. https://doi.org/10.1016/j.jfineco.2004.08.012.

18. Ameer R, Abdul Rahman R. The impact of minority shareholder watchdog group activism on the performance of targeted firms in Malaysia. Asian Academy of Management Journal of Accounting and Finance. 2009; 5(1):67-92. .

19 Chen E, Nowland J. Optimal board monitoring in family-owned companies: evidence from Asia, Corporate Governance: An International Review. 2010; 18(1):3-17.

20. Erickson J, Park Y, Reising J, Shin H. Board composition and firm value under concentrated ownership: The Canadian evidence. Pacific-Basin Finance Journal. 2005; 13:387-410. https://doi.org/10.1016/j.pacfin.2004.11.002. 
21. Barucci E, Falini J. Determinants of corporate governance in the Italian financial Market. Economic Notes by Banca Monte dei Paschi di Siena SpA. 2005; 34(3):371-405. https://doi.org/10.1111/j.0391-5026.2005.00155.x.

22. Admati A, Pfleiderer P. The 'Wall Street walk' and shareholder activism: exit as a form of voice. Review Finance Studies. 2009; 22(7):2645-85. https://doi.org/10.1093/rfs/ hhp037.

23. Bharath S, Jayaraman S, Nagar V. Exit as governance: an empirical analysis. Working Paper, W.P. Carey School of Business. Arizona State University. 2011.

24. Edmans A, Fang V, Zur E. The effect of liquidity on governance. Working Paper No. 17567. National Bureau of Economic Research. 2011. .

25. Parrino R, Sias R, Starks L. Voting with their feet: institutional ownership changes around forced CEO turnover. Journal of Financial Economics. 2003; 68(1):3-46. https:// doi.org/10.1016/S0304-405X(02)00247-7.

26. Che Ahmad A, Ishak Z, Abdul Manaf N. Corporate governance, ownership structure and corporate diversification: evidence from the Malaysian listed companies. Asian Academy of Management Journal. 2003; 8(2):67-89. .

27. Cheung Y, Rau P, Stouraitis A. Helping hand or grabbing hand? Central vs. local government shareholders in Chinese listed firms. 2009. Accessed on 1st Nov 2013. 2009. http://ssrn.com/abstract=673283 .

28. Gordon E, Henry E. Palia. Related party transaction: Associations with corporate governance and firm value. EFA 2004 Maastricht Meetings Paper No. 4377; AFA 2006 Boston Meetings Paper. 2006.

29. Ryngaert M, Thomas S. Related Party Transactions: 2007. Their Origins and Wealth Effects. Accessed on 24th May 2015. http://papers.ssrn.com/sol3/papers.cfm? abstract_ $\mathrm{id}=970689$.

30. Ge W, Drury D, Fortin S, Liu F, Tsang D. Value relevance of disclosed related party transactions. Advances in Accounting, incorporating Advances in International Accounting. 2010; 26:134-41. https://doi.org/10.1016/j. adiac.2010.02.004.

31. Cheng $\mathrm{P}$, Chen J. Related party transaction, expropriation and post-IPO performance: Chinese evidence. Accessed on 1st Nov 2013. 2006. http://efmaefm.org/Symposium2007/ peng.pdf.

32. Ying Q, Wang L. Propping by controlling shareholders, wealth transfer and firm performance: Evidence from Chinese listed companies. China Journal of Accounting. Research. 2013; 6:133-47. https://doi.org/10.1016/j. cjar.2013.02.001 .

33. Friedman E, Johnson S, Mitton T. Propping and tunneling. Journal of Comparative Economics. 2003; 31:732-50. https://doi.org/10.1016/j.jce.2003.08.004.
34. Servaes H. Tobin's $Q$ and the gains from takeovers, Journal of Finance. 1991; 46:409-19. https://doi. org/10.1111/j.1540-6261.1991.tb03758.x.

35. Franks J, Harris R, Titman S. The postmerger share price performance of acquiring firms. Journal of Financial Economics. 1991; 29:81-96. https://doi.org/10.1016/0304405X(91)90014-B.

36. Kohlbeck M, Mayhew B. Valuation of firms that disclose related party transaction. Journal of Accounting Public policy. 2010; 29:115-37. https://doi.org/10.1016/j.jaccpubpol.2009.10.006.

37. Halpern P. Corporate acquisitions: A theory of special cases? A review of event studies applied to acquisitions, Journal of Finance. 1983; 38(2):297-317. https://doi. org/10.2307/2327962.

38. Chi J, Sun Q, Young M. Performance and characteristics of acquiring firms in the chinese stock markets. 2009. Accessed on 2nd May 2015. http://www.efmaefm. org/0EFMAMEETINGS/EFMA\%20ANNUAL\%20 MEETINGS/20 09-Milan/papers/EFMA2009_0398_fullpaper.pdf.

39. Becht M, Franks J, Mayer C, Rossi S. Returns to shareholder activism: Evidence from a clinical study of the Hermes U.K. Focus Fund. ECGI Finance Working Paper No. 138, European Corporate Governance Institute (ECGI). 2006. .

40. Amzaleg Y, Barak R. Ownership concentration and the value effect of Related Party Transaction (RPTs). Journal of Modern Accounting and Auditing. 2013; 9(2):239-55.

41. Peng W, Wei K, Yang Z. Tunneling or propping: Evidence from connected transactions in China. Journal of Corporate Finance. 2011; 17:306-25. https://doi.org/10.1016/j.jcorpfin.2010.08.002.

42. Gao L, Kling G. Corporate governance and tunneling: Empirical evidence from China. Pacific-Basin Finance Journal, 2008; 16:591-605. https://doi.org/10.1016/j.pacfin.2007.09.001.

43. Jensen M, Meckling W. Theory of the firm: managerial behavior, agency costs and ownership structure. Journal of Financial Economic. 1976; 3(4):305-60. https://doi. org/10.1016/0304-405X(76)90026-X.

44. Anderson R, Reeb D. Founding family ownership and firm performance: Evidence from the S\&P 500. Journal of Finance. 2003; 58(3):1301-28. https://doi. org/10.1111/1540-6261.00567.

45. Villalonga B, Amit R. How do family ownership, control, and management affect firm value? Journal of Financial Economics. 2006; 80(2):385-417. https://doi.org/10.1016/j. jineco.2004.12.005.

46. Pindado J, Requejo I. Torre C. Family control, expropriation and investor protection: A panel data analysis of Western 
European corporations. Journal of Empirical Finance, forthcoming. 2013. .

47. Utama S, Yuniasih S. Related party transaction - efficient or abusive: Indonesia evidence, Asia Pacific Journal of Accounting and Finance. 2010; 1(1):77-102.

48. Xiao S. How do agency costs affect firm value? Evidence from China, Accessed 3rd May 2015. 2009. http://cn.ckgsb. com/frsc2009/papers/72d21803-daff- 401f-af1c-pdf.

49. M. Pagano, A. Roell, The choice of stock ownership structure; agency costs, monitoring and the decision to go public. Quarterly Journal of Economics. 1998; 113:187225. https://doi.org/10.1162/003355398555568.

50. Musallam S. Effect of ownership structure and board characteristics on firm performance: evidence from Malaysia. [PhD Thesis]. Universiti Utara Malaysia. 2013.

51. Easley D, Kiefer N, O'Hara M. One day in the life of a very common stock. Review of Financial Studies. 1997; 10:80535.

52. Gonenc H, Hermes N. Propping: Evidence from new share issues of Turkish business group firms. Journal of Multinational Financial Management. 2008; 18:261-75. https://doi.org/10.1016/j.mulfin.2007.11.002.

53. Meyer K, Estrin S, Bhaumik S, Peng M. Institutions, resources, and entry strategies in emerging economies. Strategic Management Journal. 2009; 30(1):61-80. https:// doi.org/10.1002/smj.720.

54. Wahab A, Aswadi E, How J, Verhoeven P. Corporate governance and institutional investors: evidence from Malaysia. Asian Academy of Management, Journal of Accounting and Finance. 2008; 4(2):67-90.
55. Bennedsen $M$, Nielsen $K$. Incentive and entrenchment effects in European ownership. Journal of Banking and Finance. 2010; 34:2212-29. https://doi.org/10.1016/j. jbankfin.2010.02.007.

56. Dewenter K, Han X, Malatesta P. Firm values and sovereign wealth fund investments. Journal of Financial Economics. 2010; 98:256-78. https://doi.org/10.1016/j. jfineco.2010.05.006.

57. Park Y, Selvili Z, Song M. Large outside block holders as monitors: Evidence from partial acquisitions. International Review of Economics and Finance. 2008; 17:529-45. https://doi.org/10.1016/j.iref.2007.05.006.

58. Kim K, Kitsabunnarat-Chatjuthamard P, Nofsinger J. Large shareholder, board independence and minority shareholder rights: Evidence from Europe. Journal of Corporate Finance. 2007; 13:859-80. https://doi.org/10.1016/j.jcorpfin.2007.09.001.

59. Konijn S, Kraussl R, Lucas A. Block holder dispersion and firm value. Journal of Corporate Finance. 2011; 17:1330-9. https://doi.org/10.1016/j.jcorpfin.2011.06.005.

60. Murphy D. Shrieves R, Tibbs S. Determinants of the stock price reaction to allegations of corporate misconduct: earnings, risk, and firm size effects. Knoxville: The University of Tennessee; 2004. .

61. Koay J. Effect of Corporate governance factors and MSWG Activism on cumulative abnormal returns induced by related party transaction. DBA Dissertation. Sintok: Universiti Utara Malaysia; 2015. 